\title{
Profil Asidosis Tubulus Renalis pada Anak di RS Gipto Mangunkusumo Jakarta
}

\author{
Erwin Lukas Hendrata, Taralan Tambunan, Damayanti Rusli Sjarif, Imral Chair \\ Departemen Ilmu Kesehatan Anak, Fakultas Kedokteran Universitas Indonesia - Rumah Sakit Cipto \\ Mangunkusumo, Jakarta
}

Latar belakang. Asidosis tubulus renalis (ATR) adalah suatu sindrom klinis yang disebabkan oleh gangguan reabsorpsi bikarbonat $\left(\mathrm{HCO}_{3}^{-}\right.$) di tubulus proksimal renal atau gangguan pengasaman urin (sekresi ion $\mathrm{H}^{+}$) di tubulus distal. Ditandai oleh asidosis metabolik hiperkloremik, senjang anion plasma normal, dan fungsi glomerulus normal. Sampai saat ini diagnosis ATR masih sulit ditegakkan terutama karena gejala klinis yang tidak spesifik. Tanpa pengobatan dini, adekuat, dan berkesinambungan maka anak dengan ATR berpotensi mengalami gangguan pertumbuhan, nefrokalsinosis, nefrolitiasis, osteomalasia, gagal ginjal, hiperkalemia, atau bahkan kematian.

Tujuan. Menilai profil anak dengan asidosis tubulus renalis sehingga diagnosis dan pengobatan ATR dapat dilakukan lebih dini.

Metode. Penelitian serial kasus dengan sumber data diperoleh dari rekam medis pasien ATR yang berobat di Departemen Ilmu Kesehatan Anak Fakultas Kedokteran Universitas Indonesia-Rumah Sakit Cipto Mangunkusumo (IKA FKUI-RSCM) sejak Januari 1998 hingga Desember 2008.

Hasil. Didapatkan 54 pasien ATR baru yang berarti terjadi peningkatan lebih dari 9 kali lipat dibanding penelitian terdahulu yang dilakukan pada tahun 1975-1995. Peningkatan tersebut mungkin disebabkan meningkatnya kewaspadaan petugas kesehatan terhadap gejala gagal tumbuh dan ATR diduga sebagai salah satu etiologinya. Gejala tersering yang ditemukan adalah gagal tumbuh, perawakan pendek, dan anoreksia. Nefrokalsinosis didapatkan pada $6(21 \%)$ dari 28 subjek penelitian. Setelah pemberian terapi alkali, dengan rerata lama pengamatan 20 bulan, peningkatan BB/TB terjadi pada 27/34 subjek. Peningkatan BB/TB terjadi terutama dalam 6 bulan pertama pengobatan.

Kesimpulan. Gagal tumbuh, terutama bila disertai perawakan pendek, anoreksia, dan muntah pada seorang anak dapat dipakai sebagai petunjuk untuk kemungkinan diagnosis ATR.(Sari Pediatri 2009;11(4):264-75).

Kata kunci: asidosis tubulus renalis, gagal tumbuh, terapi alkali

Alamat korespondensi

Prof. Dr. Taralan Tambunan, Sp.A(K). Divisi Nefrologi. Departemen Ilmu Kesehatan Anak Fakultas Kedokteran Universitas Indonesia. Jl. Salemba no. 6, Jakarta 10430. Telepon: 021-3915179. Fax.021-390 7743.

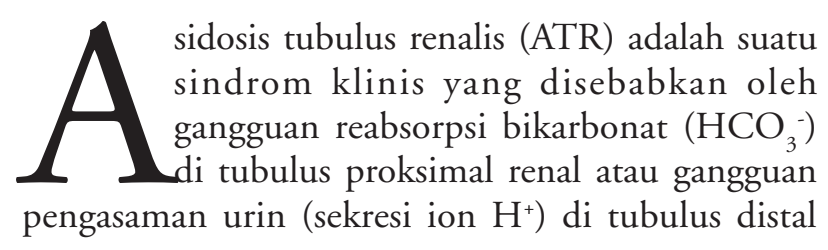

Sari Pediatri, Vol. 11, No. 4, Desember 2009 
yang ditandai oleh asidosis metabolik hiperkloremik, senjang anion plasma normal, dan fungsi glomerulus normal. ${ }^{1,2}$ Asidosis tubulus renalis sudah dikenal sejak 1941, namun sampai sekarang diagnosis ATR masih sulit ditegakkan terutama karena gejala klinis tidak spesifik sehingga sering tidak terdiagnosis atau terlambat dan tidak mendapat pengobatan. Penelitian yang dilakukan di Rumah Sakit Cipto Mangunkusumo (RSCM) dari tahun 1975-1995 ditemukan 12 kasus ATR baru. ${ }^{2,3}$ Angka kejadian tersebut masih relatif sedikit bila dibandingkan dengan penelitian-penelitian di luar negeri. Santos $\mathrm{dkk}^{4} \mathrm{di}$ Amerika Serikat menemukan 24 kasus ATR baru selama 6 tahun (1978-1984). Tanpa pengobatan dini, adekuat, dan berkesinambungan maka anak dengan ATR berpotensi mengalami gangguan pertumbuhan, nefrokalsinosis, nefrolitiasis, osteomalasia, gagal ginjal, hiperkalemia, atau bahkan kematian., 2,5-7

\section{Metode}

Penelitian adalah studi serial kasus. Data diambil dari rekam medis Departemen Ilmu Kesehatan Anak FKUI - RSCM. Subjek adalah semua anak dengan diagnosis ATR yang berobat di RSUPN Cipto Mangunkusumo selama bulan Januari 1998 sampai Desember 2008. Pencatatan rekam medis dilakukan terhadap variabel-variabel demografi (usia, jenis kelamin, riwayat penyakit dalam keluarga), klinis (gejala klinis, pemeriksaan fisis), pemeriksaan darah (elektrolit (kalium, natrium, klorida, kalsium), ureum, kreatinin, dan analisis gas darah), dan pemeriksaan urin $(\mathrm{pH}$ urin, senjang anion urin, kalsium urin, sitrat urin), serta pemeriksaan penunjang lain (USG ginjal).

Diagnosis ATR ditandai oleh asidosis metabolik hiperkloremik, senjang anion plasma normal, dan fungsi glomerulus normal. ${ }^{1,2,8}$ Kriteria asidosis metabolik apabila hasil pemeriksaan gas darah didapatkan nilai $\mathrm{HCO}_{3}{ }^{-}$di bawah $20 \mathrm{mEq} / \mathrm{L} .{ }^{9}$ Nilai normal senjang anion plasma adalah 8-16 dan senjang anion urin dinyatakan positif $(+)$ bila kadar $\left[\mathrm{Na}^{+}+\mathrm{K}^{+}\right]$ $>\mathrm{Cl}^{-}$dan negatif bila kadar $\left[\mathrm{Na}^{+}+\mathrm{K}^{+}\right]<\mathrm{Cl}^{-}$. Gagal tumbuh dinilai berdasarkan penurunan berat badan dalam kurva berat badan per umur yang menurun sampai memotong dua atau lebih garis persentil sesuai kurva CDC, dan sebelumnya memiliki kurva yang stabil. ${ }^{10}$

\section{Hasil}

Selama kurun waktu 1 Januari 1998 sampai sampai 31 Desember 2008, ditemukan 54 kasus ATR baru. Sebelas kasus dieksklusi karena rekam medis pasien tidak lengkap sehingga pada akhirnya didapatkan 43 kasus yang memenuhi kriteria penelitian.

Rentang usia subjek penelitian antara 2 bulan- 15 tahun, dengan rerata usia 3 tahun 6 bulan. Anak lakilaki 23 orang dan perempuan 20 orang. Terdapat 2 (5\%) subjek penelitian yang memiliki anggota keluarga yang memiliki keluhan yang sama. Tidak ada orangtua subjek yang memiliki hubungan konsanguinitas. Gejala terbanyak yang ditemukan pada subjek adalah gagal tumbuh (100\%), perawakan pendek (51\%), dan anoreksia (49\%). Status nutrisi saat awal diagnosis pada 9 subjek penelitian mempunyai gizi baik, 30 subjek gizi kurang dan 4 subjek gizi buruk (Tabel 1).

\section{Profil laboratorium}

Profil laboratorium anak yang menderita dengan ATR tertera pada Tabel 2. Rentang nilai $\mathrm{HCO}_{3}$ antara $11,2-19,3 \mathrm{mEq} / \mathrm{L}$, kalium $1,48-6,36 \mathrm{mEq} / \mathrm{L}$, natrium 124-149 mEq/L, klorida 92-121 mEq/L, ureum 10-98 $\mathrm{mg} / \mathrm{dL}$, dan kreatinin 0,2-0,8 mg/dL.

Tabel 1. Manifestasi klinis pasien ATR saat datang pertama kali

\begin{tabular}{lcc}
\hline Manifestasi & $\mathrm{N}$ & $\%$ \\
\hline Gejala dan tanda* & 31 & 100 \\
Gagal tumbuh* & 22 & 51 \\
Perawakan pendek & 21 & 49 \\
Anoreksia & 9 & 21 \\
Muntah & 9 & 21 \\
Lumpuh/paresis & & \\
Osteomalasia/rikets & 6 & 14 \\
(rachitic rosary, genu valgus) & 3 & 7 \\
Asidosis metabolik persisten pasca diare & 2 & 5 \\
Poliuria & 2 & 5 \\
Buang air kecil berpasir & 1 & 2 \\
Hematuria & 1 & 2 \\
Gangguan penglihatan (miopia berat) & & \\
Status nutrisi & 9 & 21 \\
Baik & 30 & 70 \\
Kurang & 4 & 9 \\
Buruk & \\
* Gejala klinis dapat lebih dari 1 pada tiap subjek. \\
\# Pada penelitian ini gejala gagal tumbuh hanya dinilai pada 31 \\
subjek berusia kurang dari 5 tahun.
\end{tabular}


Pemeriksaan senjang anion urin hanya dapat dilakukan pada $10(28 \%)$ subjek penelitian dengan hasil 8 (19\%) subjek senjang anion urin positif dan 2 (5\%) subjek didiagnosis sebagai ATR proksimal. Data pemeriksaan USG ginjal didapatkan pada 28 (65\%) subjek, 6 (14\%) subjek di antaranya menunjukkan nefrokasinosis.

Tabel 2. Hasil pemeriksaan penunjang

\begin{tabular}{lcc}
\hline Pemeriksaan penunjang & Jumlah & $\%$ \\
\hline Darah & & \\
- HC0 ${ }_{3}<20 \mathrm{mEq} / \mathrm{L}$ & 43 & 100 \\
- Kalium <3,0 mEq/L & 8 & 18 \\
- Senjang anion normal (8-16) & 43 & 100 \\
- Laju filtrasi ginjal & & \\
- Normal & 15 & 35 \\
- Menurun & 4 & 9 \\
- Tidak ada data & 24 & 56 \\
Urin & & \\
- pH >5,5 & 26 & 59 \\
- Senjang anion & 8 & 19 \\
- Positif & 2 & 5 \\
$\quad$ - Negatif & 33 & 77 \\
$\quad$ Tidak ada data & & \\
USG ginjal & 6 & 14 \\
- Nefrokalsinosis & 22 & 51 \\
- Normal & 15 & 35 \\
- Tidak ada data &
\end{tabular}

\section{Profil klinis berdasarkan tipe ATR}

Tabel 3 menggambarkan profil klinis ATR distal dan proksimal pada anak. Terdapat 10 subjek penelitian yang telah menjalani pemeriksaan elektrolit urin untuk menentukan tipe ATR, 8 diantaranya adalah ATRD dan 2 ATRP.

\section{Profil klinis ATR dengan dan tanpa nefro- kalsinosis}

Karakteristik subjek penelitian dengan dan tanpa nefrokalsinosis ditampilkan dalam Tabel 4. Dari kelompok ATR dengan nefrokalsinosis, 4 subjek terdiagnosis ATR saat berusia kurang dari 5 tahun, 1 berusia 6-12, tahun dan 1 berusia di atas 12 tahun. Pada kelompok ATR tanpa nefrokalsinosis 19 subjek terdiagnosis ATR saat berusia kurang dari 5 tahun, dan 3 subjek saat berusia 6-12 tahun.

Tiga subjek dari kelompok ATR dengan nefrokalsinosis terdiagnosis sebagai ATRD, sedangkan 3 subjek lainnya belum dilakukan pemeriksaan elektrolit urin sehingga tidak dapat ditentukan jenis ATR. Gejala klinis terbanyak pada kelompok ATR dengan nefrokalsinosis adalah gagal tumbuh (4/4 subjek), anoreksia (4/6 subjek), lumpuh (3/6 subjek),

Tabel 3. Profil klinis berdasarkan tipe ATR

\begin{tabular}{|c|c|c|}
\hline & $\operatorname{ATRD}^{* *}(\mathrm{n}=8)$ & $\operatorname{ATRP}^{* * *}(\mathrm{n}=2)$ \\
\hline \multicolumn{3}{|l|}{ Gejala dan tanda* } \\
\hline Perawakan pendek & 6 & 2 \\
\hline Anoreksia & 6 & 1 \\
\hline Gagal tumbuh ${ }^{\#}$ & 4 & Tidak dapat dinilai \\
\hline Lumpuh/ paresis & 2 & 1 \\
\hline Osteomalasia/ rikets (rachitic rosary, genu valgus) & 3 & 0 \\
\hline Muntah & 2 & 1 \\
\hline Buang air kecil berpasir & 4 & 0 \\
\hline Asidosis metabolik persisten pasca diare & 1 & 0 \\
\hline \multicolumn{3}{|l|}{ Pemeriksaan laboratorium } \\
\hline - Rentang $\mathrm{HCO}_{3}(\mathrm{mEq} / \mathrm{L})$ & $11,2-17$ & $15,3-17$ \\
\hline - Kalium $<3,0 \mathrm{mEq} / \mathrm{L}$ & 3 & 1 \\
\hline$\bullet \mathrm{pH}$ urin $>5,5$ & 8 & 0 \\
\hline \multicolumn{3}{|l|}{ USG ginjal } \\
\hline - Nefrokalsinosis & 3 & 0 \\
\hline - Normal & 3 & 2 \\
\hline - Tidak ada data & 2 & 0 \\
\hline $\begin{array}{l}\text { * Gejala klinis dapat lebih dari } 1 \text { pada tiap subjek. } \\
\text { * kedua subjek penelitian dengan ATRP berusia lebih d } \\
\text { ** ATRD }=\text { Asidosis tubular renal distal } \\
\text { ***ATRP }=\text { Asidosis tubular renal proximal }\end{array}$ & hun, sehingga gag & mbuh tidak dapat dinilai \\
\hline
\end{tabular}


Tabel 4. Profil klinis ATR dengan dan tanpa nefrokalsinosis

\begin{tabular}{|c|c|c|}
\hline Gejala klinis dan laboratorium & $\begin{array}{c}\text { ATR dengan } \\
\text { nefrokalsinosis }(n=6)\end{array}$ & $\begin{array}{c}\text { ATR tanpa } \\
\text { nefrokalsinosis }(\mathrm{n}=22)\end{array}$ \\
\hline \multicolumn{3}{|l|}{ Usia saat diagnosis ATR (bulan, \%) } \\
\hline$\cdot 1-60$ & $4(67)$ & $19(86)$ \\
\hline - 61-144 & $1(16,5)$ & $3(14)$ \\
\hline - $>144$ & $1(16,5)$ & 0 \\
\hline \multicolumn{3}{|l|}{ Tipe ATR (n, \%) } \\
\hline - ATRD & $3(50)$ & $3(14)$ \\
\hline - ATRP & 0 & $2(9)$ \\
\hline - ATRH & 0 & 0 \\
\hline - Belum ditentukan & $3(50)$ & $17(77)$ \\
\hline \multicolumn{3}{|l|}{ Gejala klinis* (\%) } \\
\hline - Gagal tumbuh\$ & $4(100)$ & $19(100)$ \\
\hline - Anoreksia & $4(67)$ & $11(50)$ \\
\hline - Pendek & $4(67)$ & $11(50)$ \\
\hline - Lumpuh/ paresis & $3(50)$ & $2(9)$ \\
\hline - Buang air kecil berpasir & $2(33)$ & 0 \\
\hline - Muntah & $2(33)$ & $5(23)$ \\
\hline - Kelainan tulang (rachitic rosary, genu valgus) & $1(17)$ & $2(9)$ \\
\hline - Hematuria & $1(17)$ & 0 \\
\hline - Asidosis metabolik persisten pasca diare & 0 & $2(9)$ \\
\hline - Poliuria & 0 & $1(4)$ \\
\hline \multicolumn{3}{|l|}{ Pemeriksaan penunjang ${ }^{\#}$} \\
\hline - Rerata pH urin & 7,1 & 6,5 \\
\hline - Rerata $\mathrm{HCO}_{3}^{-}$ & 14,85 & 14,68 \\
\hline - Kalsium urin (\%) & & \\
\hline - Normal & $1(17)$ & 0 \\
\hline - Tinggi & $1(17)$ & 0 \\
\hline - Tidak ada data & $4(66)$ & $22(100)$ \\
\hline
\end{tabular}

* Gejala klinis dapat lebih dari 1 pada tiap subjek.

$\$$ Gejala gagal tumbuh hanya dinilai pada subjek berusia kurang dari 5 tahun, yaitu 4 subjek nefrokalsinosis dan 19 subjek tanpa nefrokalsinosis.

dan pendek (4/6 subjek). Pada kelompok ATR tanpa nefrokalsinosis, gejala klinis terbanyak adalah berat badan tidak naik (19/19 subjek), anoreksia (11/22 subjek), pendek (11/22 subjek), dan muntah $(5 / 22$ subjek).

\section{Pemantauan berat badan dan tinggi badan}

Gambar 1 sampai 4 (Lampiran), menunjukkan perubahan berat badan dan tinggi badan sejak awal sampai kunjungan terakhir. Terdapat 34 pasien dengan tinggi badan dan berat badan pada saat awal diagnosis sampai kunjungan terakhir. Pasien mendapat terapi alkali dengan lama pengobatan yang bervariasi, berkisar antara 1-120 bulan dengan rerata 20 bulan.
Berdasarkan perhitungan berat badan per tinggi badan, pada akhir pengamatan terdapat 27/34 (79\%) subjek penelitian yang mengalami perbaikan status gizi. Kenaikan terbanyak terjadi pada 6 bulan pertama pengobatan alkali yaitu $76 \%$ untuk berat badan per umur dan 64\% untuk tinggi badan per umur.

\section{Pembahasan}

Sebagian subjek tidak datang kembali atau menolak ke RSCM untuk kontrol rutin sehingga tidak dapat dievaluasi hasil pengobatannya. Pemeriksaan elektrolit untuk menentukan jenis ATR, hanya dilakukan pada sebagian kecil subjek sehingga tidak dapat membeda- 
kan klinis, laboratoris, dan respon pengobatan pada tiap jenis ATR. Tidak semua subjek penelitian ini menjalani pemeriksaan fungsi ginjal. Dijumpai 54 kasus ATR selama 10 tahun terakhir (1998-2008) dengan 95\% kasus terdiagnosis setelah tahun 2000. Jumlah tersebut 9 kali lebih banyak apabila dibandingkan dengan penelitian oleh Pardede $\mathrm{dkk}^{3}$ pada tahun 1975-1995 di tempat yang sama mendapatkan 12 kasus ATR. Peningkatan tersebut disebabkan meningkatnya kewaspadaan petugas kesehatan terhadap gejala gagal tumbuh dan ATR sebagai salah satu etiologinya.

Perbandingan yang sama antara subjek lelaki dan perempuan, sampai saat ini belum ada literatur maupun penelitian yang menjelaskan perbedaan jenis kelamin untuk terjadinya ATR., ${ }^{511-13}$ Usia ratarata diagnosis ATR yaitu 3 tahun 6 bulan dengan usia termuda pada bayi usia 2 bulan dan usia tertua pada anak usia 15 tahun. Berbeda dengan penelitian terdahulu di RSCM oleh Pardede dkk ${ }^{3}$ pada tahun 1975-1995 yang mendapatkan usia rerata diagnosis adalah 5 tahun 2 bulan. Kecenderungan serupa juga terjadi pada usia diagnosis penelitian-penelitian mengenai ATR di luar negeri, yaitu dalam beberapa dekade terakhir ATR dapat didiagnosis dalam usia yang lebih muda. Penelitian Soriano dkk ${ }^{13}$ (1962-1967), Caldas $\mathrm{dkk}^{12}$ (1965-1988), dan Santos dkk ${ }^{4}$ (19781984) melaporkan rerata usia diagnosis ATR secara berturut-turut 4 tahun 6 bulan, 3 tahun 3 bulan, dan 8 bulan.

Hanya didapatkan dua subjek yang memiliki riwayat keluarga dengan gejala serupa. Salah satu subjek penelitian memiliki keluhan yang sama dengan kakaknya yaitu lumpuh, sedangkan satu subjek lainnya memiliki keluhan keluar pasir saat berkemih yang juga dialami oleh pamannya. Penelitian oleh Caldas $\mathrm{dkk}^{12}$ mendapatkan 10 dari 28 subjek mempunyai riwayat keluarga yang menderita ATR, yang kemungkin berhubungan dengan tingginya kejadian konsanguinitas orangtua pada penelitian tersebut. Gejala yang paling sering ditemukan pada pasien ATR adalah gagal tumbuh. Seluruh subjek penelitian yang berusia di bawah 5 tahun mengalami gagal tumbuh. Penelitian oleh Pardede dkk, ${ }^{3}$ Santos dkk, ${ }^{4}$ Nash dkk, ${ }^{5}$ Caldas dkk, ${ }^{12}$ dan McSherry dkk ${ }^{14}$ melaporkan gangguan pertumbuhan merupakan gejala ATR tersering pada anak. Santos $\mathrm{dkk}^{4}$ melaporkan $50 \%$ subjek penelitiannya mengalami gangguan pertumbuhan, demikian pula dengan Nash $\mathrm{dkk}^{5}$ yang mendapatkan 12 dari 13 pasien terdapat gangguan pertumbuhan. Penelitian Pardede $\mathrm{dkk}^{3}$ mendapatkan 11 dari 12 subjek penelitiannya terdapat gangguan pertumbuhan namun hanya satu subjek yang datang berobat dengan keluhan utama tersebut. Hal tersebut mungkin disebabkan pada saat penelitian oleh Pardede $\mathrm{dkk}^{3}$ dilakukan, tingkat kewaspadaan orangtua terhadap gangguan pertumbuhan anak masih kurang dan pengetahuan tenaga kesehatan mengenai kemungkinan ATR sebagai penyebab gangguan pertumbuhan juga masih kurang, sehingga subjek datang berobat dengan gejala yang lebih berat atau sudah terjadi komplikasi.

Perawakan pendek didapatkan pada 22 dari 43 subjek penelitian. Hasil yang berbeda dilaporkan oleh Pardede $\mathrm{dkk}^{3}$ yang mendapatkan 10/12 pasien ATR memiliki tinggi badan di bawah persentil 3 kurva pertumbuhan. Kemungkinan penyebab perbedaan tersebut adalah usia diagnosis pada penelitian tersebut lebih tua dibanding penelitian ini ( 5 tahun 2 bulan) sehingga sebagian besar subjek penelitian sudah mengalami gangguan pertumbuhan tinggi badan. Ditemukan 21/43 subjek mengalami anoreksia. Penelitian Santos $\mathrm{dkk}^{4}$ mendapatkan gejala anoreksia dan muntah pada 9/24 subjek dengan ATR. Dari hasil penelitian kami dan penelitian lainnya, maka ATR patut dicurigai sebagai salah satu etiologi pada anak dengan gejala gagal tumbuh, terutama bila disertai perawakan pendek dan anoreksia.

Lumpuh atau tidak dapat berjalan didapatkan pada 7/43 subjek penelitian ini, kemungkinan besar merupakan gejala ATR yang terlambat diobati sehingga terjadi kelemahan otot tungkai akibat hipokalemia. Seluruh subjek penelitian dengan gejala lumpuh didapatkan kadar kalium serum yang rendah, dengan rentang antara 1,48 sampai $3 \mathrm{mEq} / \mathrm{L}$. Penelitian Pardede $\mathrm{dkk}^{3}$ mendapatkan 7 dari 12 subjek datang dengan keluhan lumpuh. Hal ini sesuai dengan proporsi hipokalemia pada penelitian Pardede dkk yang mencapai $75 \%$. Santos $\mathrm{dkk}^{4}$ melaporkan hipokalemia terjadi pada sebagian besar pasien ATR. Hal tersebut berbeda dengan penelitian kami yang hanya menemukan hipokalemia pada $18 \%$ subjek. Kemungkinan perbedaan diakibatkan batas hipokalemia yang dipakai pada penelitian Santos ${ }^{4}$ di bawah 3,8 $\mathrm{mEq} / \mathrm{L}$, sedangkan penelitian kami di bawah $3 \mathrm{mEq} / \mathrm{L}$.

Pemeriksaan fungsi ginjal dilakukan pada 19 subjek dan terdapat 4 (21\%) subjek dengan insufisiensi ginjal. Dua dari 4 subjek tersebut didapatkan nefrokalsinosis 
yang kemungkinan menyebabkan penurunan fungsi ginjal, satu subjek kemungkinan akibat kondisi dehidrasi saat dilakukan pemeriksaan fungsi ginjal, sedangkan satu subjek tidak diketahui penyebabnya.

Penelitian kami dan penelitian Nash $\mathrm{dkk}^{5}$ melaporkan tidak terdapat perbedaan gejala klinis baik ATRD maupun ATRP, yang umumnya adalah gejala non spesifik. Nefrokalsinosis didapatkan pada 3/8 subjek ATRD. Dua dari 8 subjek (usia 2 bulan dan 5 tahun) juga ditemukan nefrolitiasis dan memberikan gejala spesifik berupa buang air kecil (BAK) berpasir, sedangkan satu subjek (usia 13 tahun) belum memberikan gejala spesifik. Hasil penelitian kami sesuai dengan kepustakaan yang menyebutkan bahwa nefrokalsinosis umumnya asimtomatik kecuali apabila telah disertai nefrolitiasis. ${ }^{16}$

Secara keseluruhan, dari 28 subjek yang telah diperiksa USG ginjal didapatkan 6 (21\%) subjek dengan nefrokalsinosis, 3 diantaranya merupakan ATRD sedangkan 3 lainnya tidak diketahui jenis ATR. Brenner dkk ${ }^{15}$ melaporkan 29\% dari 92 anak pasien ATR telah didapatkan nefrokalsinosis, yang seluruhnya terjadi pada ATRD. Pardede $\mathrm{dkk}^{3}$ mendapatkan nefrokalsinosis $17 \%$, sedangkan penelitian oleh Caldas $\mathrm{dkk}^{12}$ mendapatkan pada 50\% subjek. Jumlah nefrokalsinosis yang cukup banyak pada penelitian Caldas dkk kemungkinan akibat semua subjek penelitiannya adalah ATRD.

Usia termuda diagnosis nefrokalsinosis pada penelitian kami 2 bulan dan usia tertua 19 tahun. Penelitian Rodriguez-Soriano $\mathrm{dkk}^{7}$ pada 5 bayi ATRD (usia rerata 7 bulan) menemukan 3 subjek menderita nefrokalsinosis. Penyebab nefrokalsinosis pada anak atau dewasa pasien ATR kemungkinan akibat pengobatan yang terlambat atau tidak teratur, tetapi pada bayi kemungkinan akibat tingginya persentase ATR dengan penyebab primer yang dilaporkan memiliki risiko lebih tinggi untuk terjadi nefrokalsinosis. ${ }^{7}$ Kemungkinan lain adalah ATR terjadi sekunder akibat hiperkalsiuria herediter. ${ }^{16}$

Ronnefarth $\mathrm{dkk}^{17}$ melaporkan perbedaan temuan atau gejala utama pada pasien ATR dengan nefrokalsinosis dibandingkan penyebab nefrokalsinosis lainnya adalah adanya gagal tumbuh. Pada penelitian kami gagal tumbuh didapatkan pada seluruh pasien ATR dengan nefrokalsinosis yang berusia kurang dari 5 tahun, tetapi gagal tumbuh juga merupakan gejala terbanyak dari ATR secara keseluruhan. Maka apabila dijumpai gagal tumbuh akan meningkatkan kecurigaan adanya ATR tetapi tidak menunjukkan adanya komplikasi nefrokalsinosis.

Berdasarkan kepustakaan, beberapa faktor biokimia/hasil laboratoris kemungkinan berpengaruh terhadap pembentukan batu atau nefrokalsinosis pada pasien ATR, antara lain hiperkalsiuria, hipersitraturia, dan $\mathrm{pH}$ urin yang basa. ${ }^{18}$ Pada penelitian kami hanya 2 subjek yang terdapat hasil pemeriksaan kalsium urin dan tidak ada satupun yang dilakukan pemeriksan sitrat urin. Penelitian oleh Caruana dkk ${ }^{19}$ dan Caldas $\mathrm{dkk}^{12}$ melaporkan tidak terdapat hubungan yang bermakna antara kejadian nefrokalsinosis dengan faktor-faktor biokimia tersebut. Mengingat masih belum ditemukan penyebab pasti maupun faktor-faktor risiko terjadinya nefrokalsinosis pada ATR, maka terapi alkali yang adekuat disertai USG ginjal berkala mutlak diperlukan untuk mencegah dan mendeteksi dini komplikasi nefrokalsinosis.

Saat awal diagnosis pada 34 dari 43 subjek penelitian termasuk dalam gizi kurang atau buruk. Dari Gambar 1 hingga 4 tampak bahwa sebagian besar subjek mengalami perbaikan status gizi. Terdapat 5 subjek yang berusia $<3$ tahun yang tidak mengalami perbaikan status gizi berdasarkan BB/TB. Satu subjek berusia 4 bulan dengan diagnosis sindrom Down dan hipotiroid, sehingga kemungkinan terdapat faktor lain yang dapat mempengaruhi pengobatan alkali pada ATR. Satu subjek lainnya berusia 2 bulan dan sudah terdapat nefrokalsinosis pada pemeriksaan USG ginjal, sehingga kemungkinan ATR pada subjek tersebut merupakan bagian dari suatu sindrom atau kelainan bawaan yang dapat mempengaruhi perbaikan status gizi. Tiga pasien lainnya hanya datang kontrol satu kali dengan jarak antara diagnosis dan waktu kontrol antara 2-3 bulan, sehingga kemungkinan belum terjadi perbaikan status gizi. Subjek tersebut berulang kali menjalani perawatan di rumah sakit karena mengalami diare yang kemudian didiagnosis sebagai alergi susu sapi.

Pada subjek penelitian yang berusia lebih dari 3 tahun, terdapat 2 subjek yang tidak mengalami perbaikan status gizi. Satu subjek tidak menjalani pengobatan secara teratur, terbukti saat dilakukan pemeriksaan USG pada umur 12 tahun sudah didapatkan nefrokalsinosis serta berulang kali datang kontrol ke RSCM dalam keadaan lumpuh akibat hipokalemia. Satu subjek lainnya hanya datang kontrol 1 kali (dengan jarak satu tahun dari awal pengobatan) dan tidak meminum bikarbonat natrikus dengan teratur. 
Kenaikan nilai berat badan/tinggi badan terbanyak terjadi pada 6 bulan pertama pengobatan alkali yaitu 17/34 subjek. Saat akhir pengamatan, perbaikan terjadi pada 27/34 subjek. McSherry $\mathrm{dkk}^{14}$ mendapatkan seluruh subjek penelitiannya $(n=10)$ mengalami peningkatan berat badan dan tinggi badan yang bermakna. Penelitian oleh Caldas $\mathrm{dkk}^{12}$ dengan rerata lama pengamatan 10 tahun pada 28 pasien ATRD mendapatkan hanya satu pasien yang tidak terjadi peningkatan berat badan dan tinggi badan yang signifikan akibat pengobatan yang tidak teratur. Perbedaan ini kemungkinan disebabkan penelitianpenelitian tersebut merupakan penelitian prospektif sehingga keteraturan berobat lebih diperhatikan. Sebagai kesimpulan, gejala gagal tumbuh, terutama bila disertai perawakan pendek, anoreksia dan muntah pada seorang anak, dapat dipakai sebagai petunjuk untuk kemungkinan diagnosis ATR. Setelah pemberian terapi alkali, sebagian besar subjek terjadi peningkatan status gizi terutama dalam enam bulan pertama pengobatan.

\section{Daftar Pustaka}

1. Dell KRM, Avner ED. Renal tubular acidosis. Dalam: Behrman RE, Kleigman RM, Jenson HB, penyunting. Nelson's textbook of pediatrics. Edisi ke-17. Philadelphia: WB Saunders;2004. h.1758-61.

2. Herrin JT. Renal tubular acidosis. Dalam: Barrat TM, Avner ED, Harmon WE, penyunting. Pediatrics nephrology. Edisi ke-4. Baltimore: William \& Wilkins; 1999. h.565-75.

3. Pardede SO, Trihono PP, Tambunan T. Gambaran klinis asidosis tubulus renalis pada anak. Sari Pediatri 2003;4:192-7.

4. Santos F, Chan JCM. Renal tubular acidosis in children. Am J Nephrol 1986;6:289-95.

5. Nash MA, Torrado AD, Greifer I, Spitzer A, Edelmann CM. Renal tubular acidosis in infants and children. J Pediatr 1972;80:738-48.

6. Rodriquez-Soriano J. Renal tubular acidosis. Dalam: Edelmann CM, penyunting. Pediatric Kidney Disease.
Edisi ke-2. Boston: Little Brown;1992. h.1737-60.

7. Rodriguez-Soriano J, Vallo A, Castillo G, Oliveros R. Natural history of primary distal renal tubular acidosis treated since infancy. J Pediatr 1982;101:669-76.

8. Chan JCM. Renal tubular acidosis. J Pediatr 1983; 102:327-40

9. Beattie TJ. Disorder of fluid and electrolyte balance. Dalam: Webb N, Postlethwaite R, penyunting. Paediatric Nephrology. Edisi ke-3. Oxford: Oxford University Press;2003. h.78.

10. Tambunan T. Tubulopati. Dalam: Alatas H, Tambunan T, Trihono PP, Pardede SO, penyunting. Buku Ajar Nefrologi Anak. Edisi 2. Jakarta: Balai Penerbit FKUI;2002. h.470-89.

11. Roth, KS, Chan JCM. Renal tubular acidosis: a new look at an old problem. Clin Pediatr 2001;40:533-43.

12. Caldas A, Broyer M, Dechaux M, Kleinknecht C. Primary distal tubular acidosis in childhood: clinical study and long-term follow-up of 28 patients. J Pediatr 1992;121:233-41.

13. Rodriguez-Soriano J, Boichis H, Edelmann CM. Bicarbonate reabsorption and hydrogen ion excretion in children with renal tubular acidosis. J Pediatr 1967;71:802-13.

14. McSherry E, Morris RC. Attainment and maintenance of normal stature with alkali therapy in infants and children with classic renal tubular acidosis. J Clin Invest 1978;61:509-27.

15. Brenner RJ, Spring DB, Sebastian A, McSherry EM, Genant HK, Palubinskas AJ, dkk. Incidence of radiographically evident bone disease, nephrocalcinosis, and nephrolithiasis in various types of renal tubular acidosis. N Engl J Med 1982;307:217-22.

16. Buckalew VM. Nephrolithiasis in renal tubular acidosis. J Urol 1989;141:731-7.

17. Ronnefarth G, Misselwitz J. Nephrocalcinosis in children: a retrospective survey. Pediatr Nephrol 2000;14:1016-21.

18. Curhan GC. Nephrolithiasis in renal tubular acidosis. [diakses tanggal 13 Juni 2009]. Diunduh dari www. uptodate.com.

19. Caruana RJ, Buckalew VM. The syndrome of distal (type 1) renal tubular acidosis. Medicine 1998;67:84-99. 


\section{Lampiran}

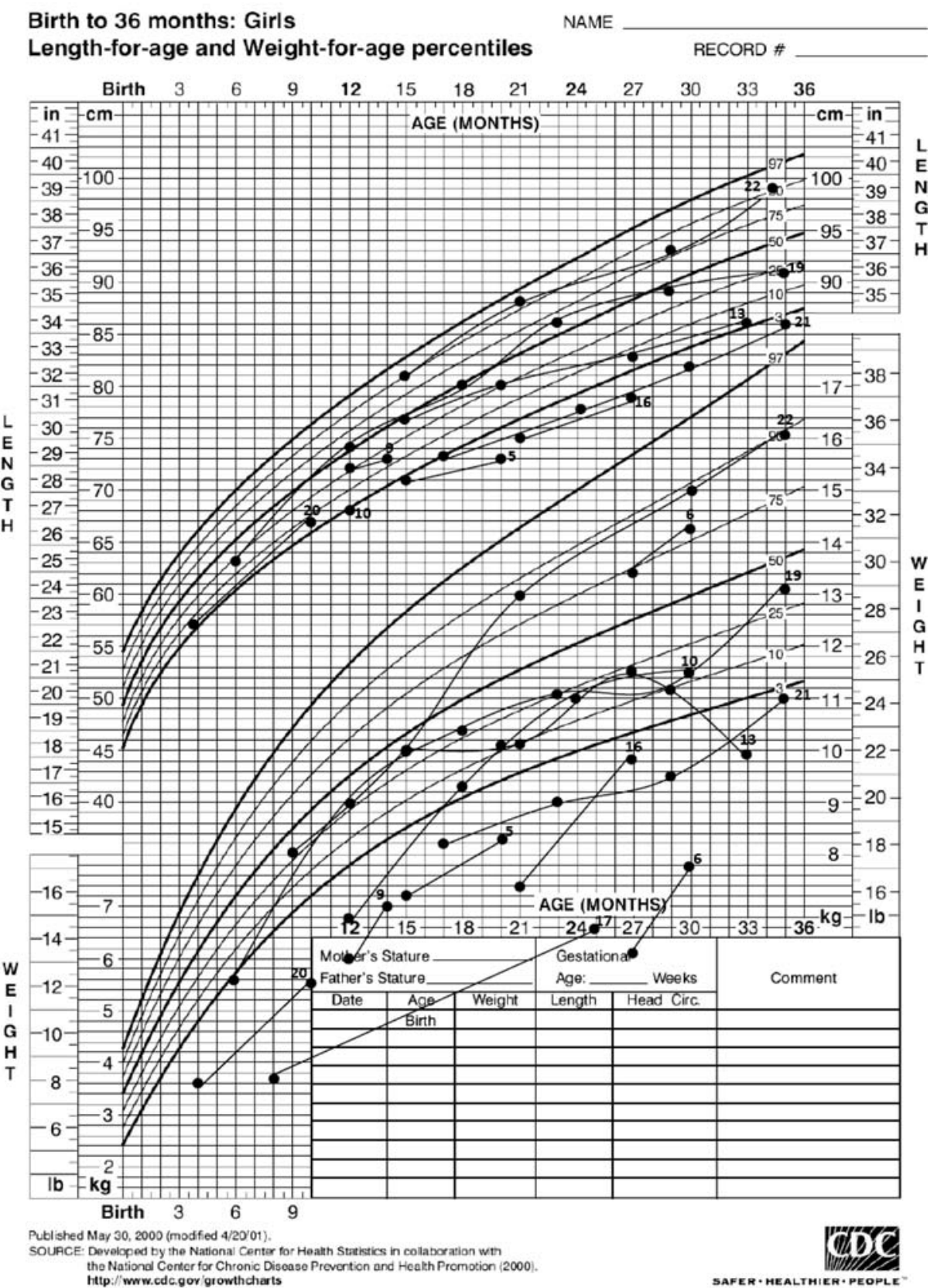

Gambar 1. Pemantauan berat badan dan tinggi badan subjek perempuan usia $<36$ bulan 


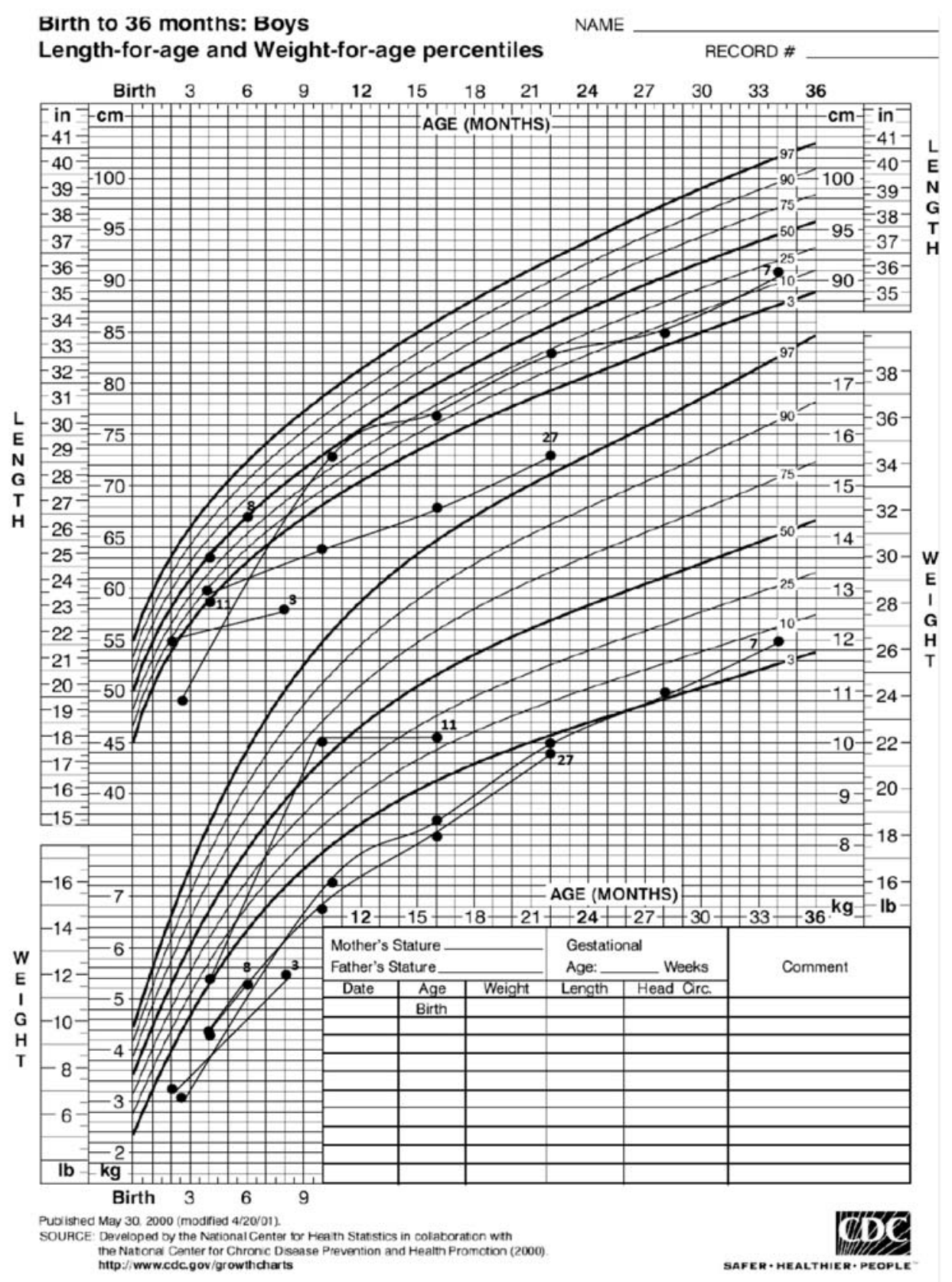

Gambar 2. Pemantauan berat badan dan tinggi badan subjek lelaki usia $<36$ bulan 
2 to 20 years: Girls Stature-for-age and Weight-for-age percentiles

NAME

RECORD \#

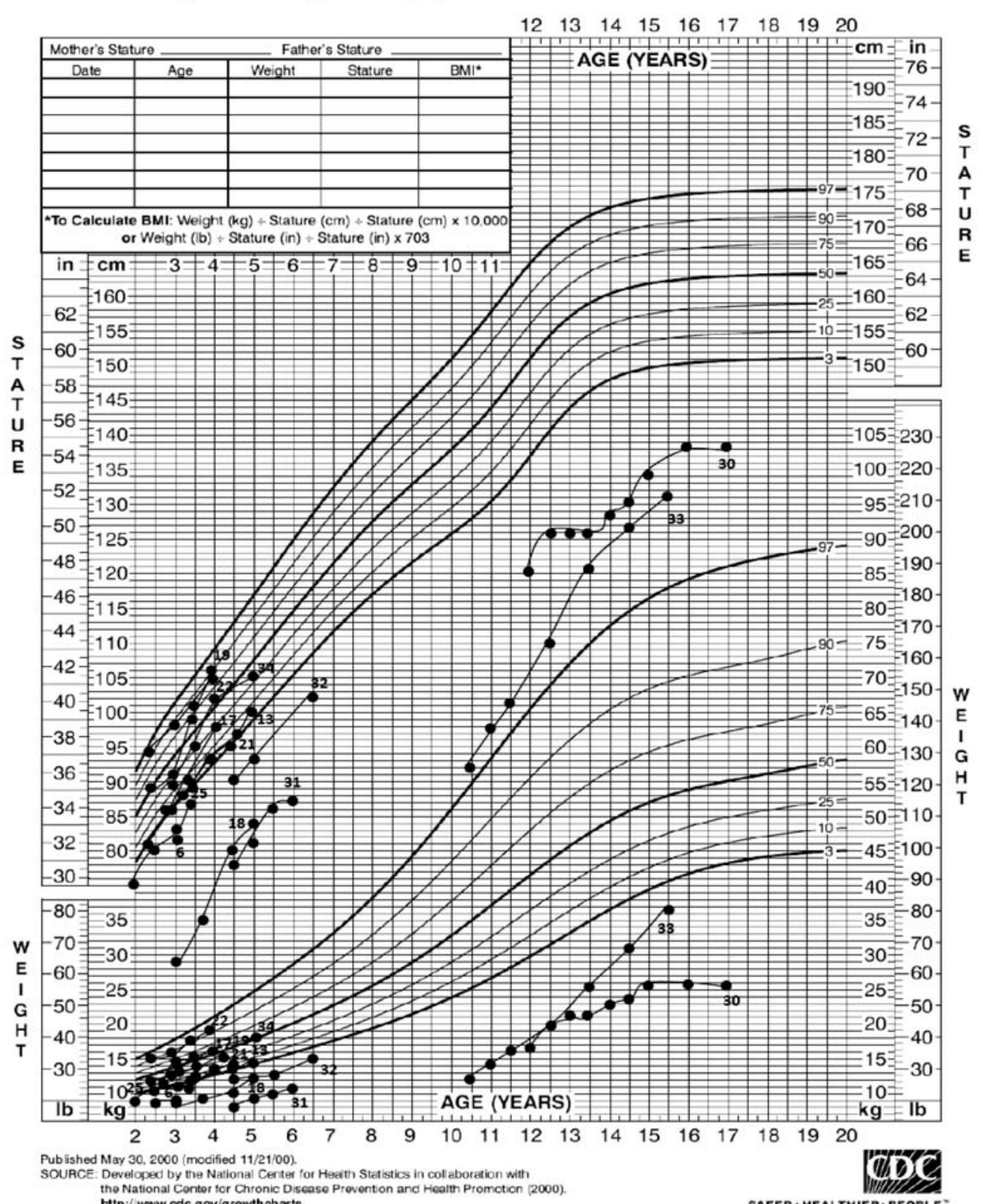

Gambar 3. Pemantauan berat badan dan tinggi badan subjek perempuan usia $>2$ tahun 
2 to 20 years: Boys Stature-for-age and Weight-for-age percentiles
NAME

RECORD \#

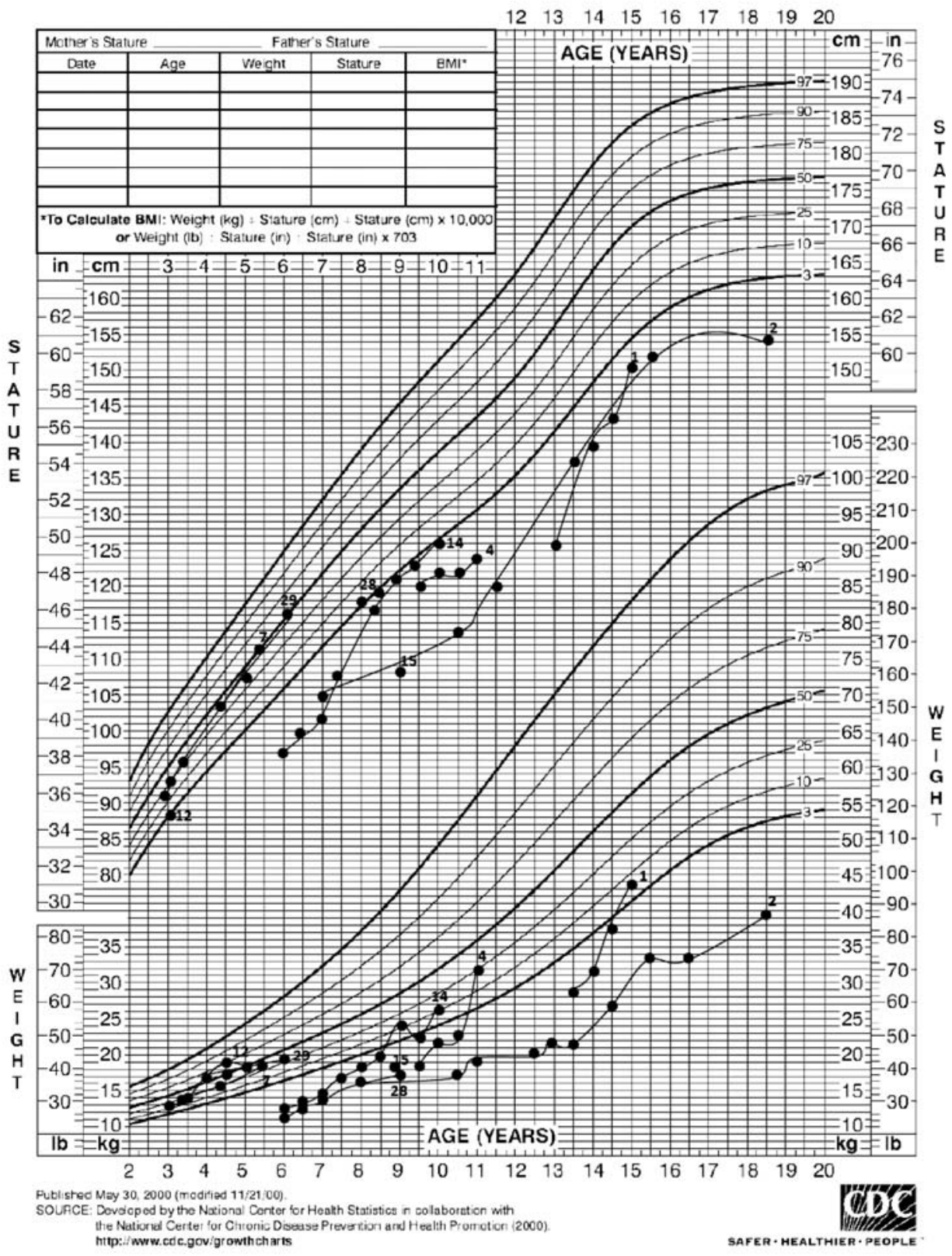

Gambar 4. Pemantauan berat badan dan tinggi badan subjek lelaki usia $>2$ tahun 


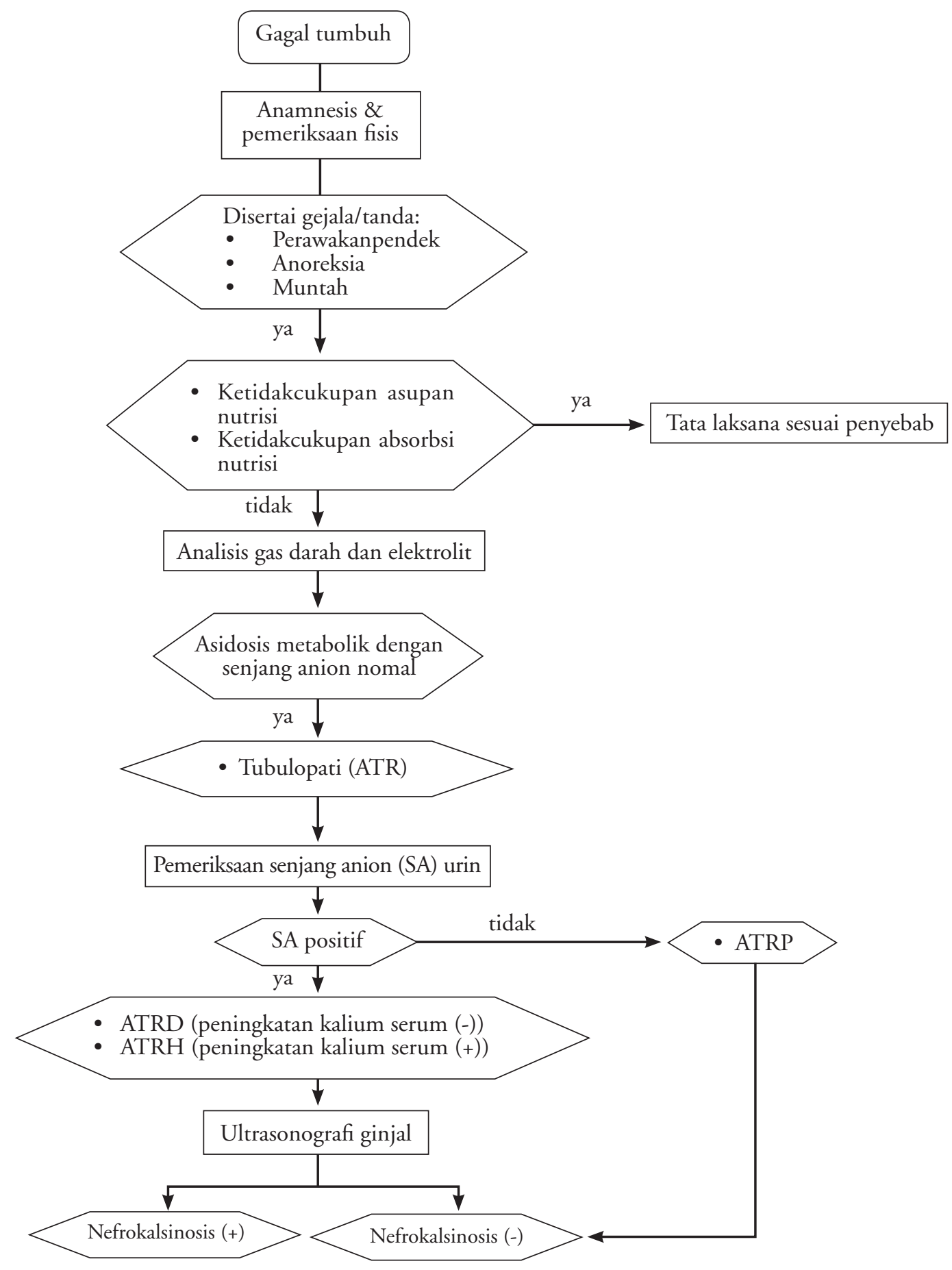

Gambar 5. Algoritme pendekatan diagnosis ATR pada anak dengan gejala gagal tumbuh 